\title{
Impact of Covid 19 - Lockdown on Private Schools in Nigeria: Evidence in FCT
}

\author{
Abdul K. I. Zubair (PhD) \\ Senior Lecturer \\ Baze University \\ Former Ag DG Securities and Exchange Commission \\ Nigeria
}

\begin{abstract}
The COVID-19 pandemic is the most widely discussed health phenomenon in recent history. This global pandemic has spread almost all countries and continents of the world. The pandemic has undoubtedly impacted on global economic growth leading to review of the global outlook by most rating agencies. The policy makers were confronted with decision dilemma of either saving lives or continue the pursuit of political and economic gains. The bitter bill of shutting down businesses, schools inclusive, crystalizes the dilemma. These interruptions will not just be a short-term issue, but can also have long-term consequences for the affected stakeholders. School lockdown disruptions to daily routine affects psychological wellbeing, academic, education approaches and finance models. The degree of impact on stakeholders varies. Covid19 is novel with little or no evidence on its impact hence the need to investigate the phenomenon. A total of 291 participants located in the 5 local government areas were involved in the survey. The survey data was tested for validity, reliability and value. Interview complimented the quantitative data. Even though a short period of schooling lockdown, the effect provides a guide to reasonably peep into likely possible outcomes as an extremely rough measure of the impact of the current school closures. The real quantitative impact will be better analysed post lockdown and covid19 era. This paper adopts regression research design in the analysis, specifically, smart PLS modelling was used. The study has implications on students, parents, leadership of schools, and operators of businesses on campus. The study further provides concept deployment, evidence from Federal Capital Territory (FCT), Nigeria and useful addition to theory, literature and practice. The study found that 10 of the 12 hypotheses were supported and 2 unsupported. In addition, change oriented leadership moderated the relationships. The underpinning theory, change oriented leadership, the methodology, and implications of quantitative and qualitative data were discussed. The paper concludes that there is a significant positive relationship between change oriented leadership and the independent variable thereby confirming the model theorised. Also the compliments of interview result reinforced the postulation. In conclusion, the present study has added valuable theoretical, practically and methodologically to the growing body of knowledge in the field of social sciences and management.
\end{abstract}

Keywords: Covid19, Pandemic, Lockdown, Academic disruption, Change in approaches in education, Changeoriented leadership

\subsection{Introduction}

The COVID-19 pandemic is the most widely discussed health phenomenon in recent history. The outbreak (previously 2019-nCoV) was caused by the SARS-CoV-2 virus. This outbreak was triggered in December 2019 in Wuhan city in Hubei province of China. COVID-19 continues to spread across the world. As of the time of writing this paper, more epicentres have been identified viz; Iran, Italy, Japan, South Korea Spain and USA. Even though the cases reported from China are expected to have peaked and are now falling (WHO, 2020). According to congressional report services (CRS) report (26 March, 2020) this global pandemic has spread to over 150 countries and all U.S. states. The pandemic has transformed into an economic and labour market shock, impacting not only supply (production of goods and services) but also demand (consumption and investment). Many countries have decided to close schools, colleges and universities. Lockdown of education institutions could cause major disruptions to daily routine, psychological wellbeing, academic, education approaches and finance models. Teaching is moving online, on an untested and unprecedented scale. Student assessments are also moving online, with a lot of trial and error and uncertainty for everyone. The reality is that the world is confronted with the dilemma of closing schools (reducing contact and saving lives) and keeping them open (allowing workers to work and maintaining the economy). In Nigeria, like most other countries, it is especially a challenging decision but painfully, crystalized by Locked down of Schools.

Although the sheer magnitude of the shock and the unfolding of the pandemic make it especially challenging to forecast economic impact, the distinct possibility of a global recession has become concrete. The most recent OECD forecast (27 March, 2020) indicates that the initial direct impact of the shutdown could be a decline in the level of output of one-fifth to one-quarter in many economies, with consumers' expenditure potentially dropping by around one-third. 
The implication for annual GDP growth is estimated in a decline of up to 2 percentage points for each month that strict containment measures continue, although this impact will depend on many factors, including the duration and magnitude of national shutdowns, the extent of reduced demand for goods and services in other parts of the economy, and the speed at which significant fiscal and monetary policy support takes effect.This paper is a modest attempt to investigate the impact of Covid19 on Schools in Nigeria: evidence in Federal Capital Territory (FCT).

\subsection{Literature Review}

United Nations Conference on Trade and Development (UNCTAD) has calculated that the impact of the coronavirus in People's Republic of China (hereafter 'China') has cost global value chains 50 billion USD in exports. Whereas in early March UNCTAD expected FDI could shrink by 5-15\%6, on 26 March the forecast was revised to a reduction by 30-40\% in 2020-21.7 The ILO estimates the impact of COVID-19 to result in a rise in global unemployment of between 5.3 million ("low" scenario) and 24.7 million ("high" scenario), signalling that 'sustaining business operations will be particularly difficult for Small and Medium Enterprises (SMEs)'. Like the OECD, the IMF has published a number of reflections on the expected disruptions to production, initially in Asia, have now spread to supply chains across the world. All businesses, regardless of size, are facing serious challenges, especially those in the aviation, tourism and hospitality industries, with a real threat of significant declines in revenue, insolvencies and job losses in specific sectors. Sustaining business operations will be particularly difficult for Small and Medium Enterprises (SMEs). Following travel bans, border closures and quarantine measures, many workers cannot move to their places of work or carryout their jobs, which has knock-on effects on incomes, particularly for informal and casually employed workers. Consumers in many economies are unable or reluctant to purchase goods and services. Given the current environment of uncertainty and fear, enterprises are likely to delay investments, purchases of goods and the hiring of workers.

Severe acute respiratory syndrome, SARS-CoV-2 (the virus that causes COVID-19) is the latest member of the corona virus family affecting humans. This type of virus is commonly found in humans and other mammals. In humans, coronavirus has four strains that cause mild clinical symptoms, usually referred as the common cold. The most recent data show that COVID-19 is likely to be more contagious but less likely to cause severe clinical symptoms and deaths than SARS and MERS (Middle East respiratory syndrome). A Chinese clinical study recorded 72,314 COVID-19 cases diagnosed by February 11, showing an overall CFR of 2.3 percent, with 81 percent of cases being mild. The CFR jumped to 8 percent among patients 70-79 years old and to 14.8 percent among patients 80 years old and older. Most COVID-19 patients have mild symptoms, similar to a flu. People with mild symptoms might not go to the hospital or even necessarily know that they have the disease but could still carry the infection. Accordingly, person-to-person transmission is not limited to hospital settings, which is what happened in the SARS and MERS cases. COVID-19 is transmitted via droplets and fomites (contact with contaminated surfaces). Data synthesis from several preliminary reports on COVID-19 indicates a coronavirus patient, on average, can transmit the disease to three people without intervention (compared with one for the common influenza, two for Ebola, and 18 for the measles).The World Health Organization (WHO) reported that such transmission in China occurred most often at the household level, as 78 to 85 percent of disease clusters were family clusters. The moderately high infectivity, mild clinical symptoms, uncertain incubation period, no human immunity, and possibility of asymptomatic healthy carriers may mean that the novel virus is likely to cause worldwide transmissions.

\subsection{Theoretical Framework}

Present study focuses on theory testing and verification rather than developing a new theory, therefore the following theories were reviewed.

\section{Cultural Model of Educational Management}

This model of educational management is based on some concepts such as ideas, beliefs, norms, values, attitudes, symbols, rituals, traditions and ideologies which considered as central to organizations and the members behave and assess the behavior of other members based on them. Moreover, it focuses on how understanding and viewpoints of members are integrated into common organizational meanings (Bush, 2010). The most relevant leadership style to be aligned with cultural models of educational management is moral leadership which stresses in the values, beliefs and ethics of leaders in the organization (Bush, 2010). As cited by Bush (2010), some other terms have also been used by scholars to define moral or values-based leadership including ethical leadership (Begley, 2007; Starratt, 2004), authentic leadership (Begley, 2007), spiritual leadership (Woods, 2007), and poetic leadership (Deal, 2005) Theodossin (1983) linking subjective model with formal model.

Hybrid model of Gronn (2010) is also another synthesis linking singular and distributed leadership. It is obvious that the environment of educational institutions is completely opaque and in turmoil and there has been always a need for adaptation to the environment as well as reorientation in policy making in this sector. 
In fact, charting change and transformation programs is a must for educational institutions to be successful and sustainable. Based on this, although the typology provided by Bush (2010) has been a great contribution to the field of educational management, however change-oriented leadership style, which is pertinent in turbulent environments (Arvonen, 2008; Ekvall \& Arvonen, 1991; Yukl, 1999, 2012a), has not been linked with any educational models. Based on these empirical and theoretical gaps, it was conceptualised that change oriented leadership role as a moderating value can explain the relationship and perspectives with the dependent variable

\section{Change-oriented leadership Model}

This style of leadership concerns about identification of threats and opportunities through monitoring the environment, proposing new strategies as well as building new visions, innovative thinking encouragement and risk taking for advancement of change initiatives within the organization (Yukl, Gordon, \& Taber, 2002).

It may be argued that transformational leadership implies charting transformations in organizations. However, based on the comparison made by Yukl (2004) between transformational, charismatic and change-oriented leadership, the latter leadership style has some specific features that do not exist in transformational and charismatic leadership and thus, change-oriented leadership is conceptualized as a more comprehensive leadership style in a turbulent environment. It must be noted that change-oriented leadership is based on the belief that human society keeps on evolving continuously, therefore learning lessons of the past and anticipating what is going to happen in future become the necessary beginning point. Change-oriented leadership seeks to improve the entire education system of a country or a school organization which has been afflicted with hindrances, conflicts, and turmoil that have prevented it from progressing forward and becoming better. Any model or theory on leadership becomes irrelevant if it does not bring improvement. A change-oriented leader tries to promote exploration of new and better ways of doing things, or trying to uncover hidden potential in people, things or situations. Since change-oriented leadership is conceptualized as a more comprehensive leadership style in a turbulent environment and going by the pandemic and the rapid manner in which events are unfolding, it could be safe to suggest that we are in turbulent times and therefore this paper adopts the change-oriented leadership as the underpinning theory to investigate the impact of covid19 on schools in FCT, Nigeria because change causes revamping of habits, values, and shift in education approaches. The study also adopts Yuki (1999) "change-oriented leadership as a unidimensional construct with 6 items".

\subsection{Conceptual frame work}

Flowing from the change-orientation model, which is the under pining theory for this paper (moderator), the author has explained pictorially in fig. 1 (below) to suggest that the lockdown arising from covid19 (Independent variable) affects psychological wellbeing, academic disruptions, shift in education approaches and finance model (Dependent variable) while Change-oriented leadership as a moderating variable links all mediators/ consequences. The extent of impact and degree of significance on each measured variables and the implication thereof are as in results and discussions.

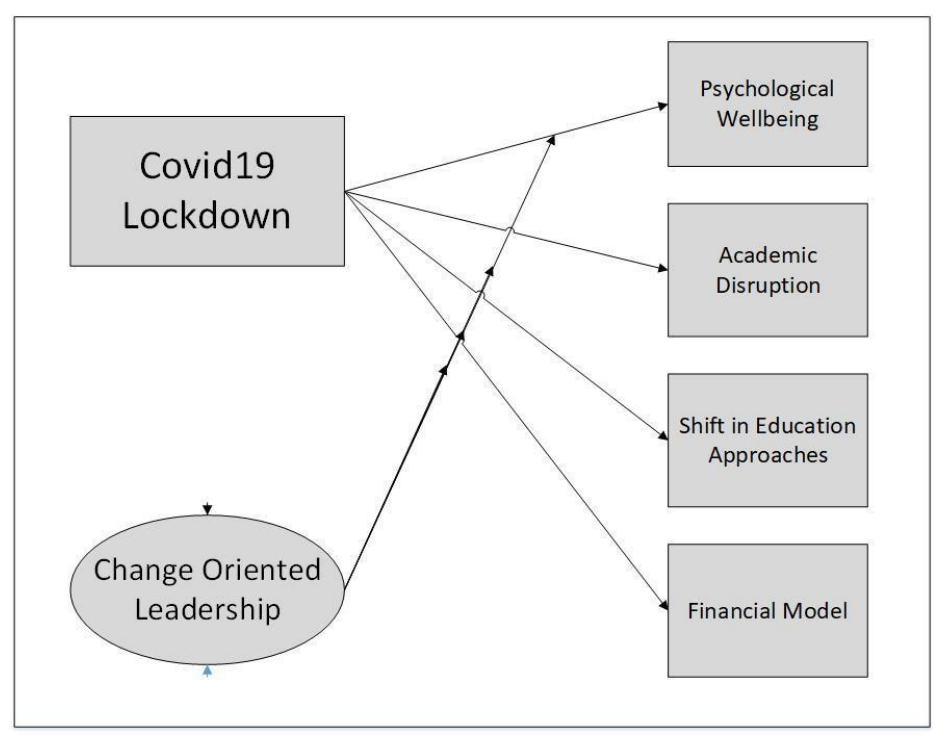

Fig 1 - Source: Zubair (2020) 


\subsection{Methodology}

In this study, mixed method was used to collect data through structure questionnaire and interview. Structured questionnaire was considered as appropriate because it is a widely used method adopted by organisational researchers who are interested in collecting information about a very large population that cannot be observed directly (Keeter, 2005; Tanur, 1982). On the other hand, the interview (qualitative) complimented the quantitative data. This paper adopts correlational and regression research design to examine the impact of covid 19 on private schools in FCT, Nigeria. The choice of this design is informed by the effectiveness of the method in investigating the relationships among theoretically related variables. A two-step methodology was used to investigate the lockdown impact on private schools in FCT, Nigeria. The first is the questionnaire on the four constructs (DV), Lockdown and change oriented leadership (IV) while the second step is the interviews using the 6 items unidimensional construct (Yuki, 1999). The population of this study comprises 291 persons using convenience random technique from private primary, secondary schools and tertiary institutions in 5 area councils of FCT. Based on the research model developed, the present study focuses on theory testing and verification rather than developing a new theory, thus, employing a deductive research approach. The model theorised that a high change oriented leadership will introduce strategies to reduce impact of lockdown while low oriented leadership will not, in essence, change oriented leadership has significant moderating effect on the measured variables. In view of identified gap, the theoretical consideration and conceptual frame work, 12 hypotheses were formulated and tested (see table 8 )

\subsection{Techniques of Data Analysis}

The study employed Smart PLS (family of regression models) to test several hypotheses. 12 hypotheses were formulated and tested using this technique of data analysis. As suggested by Breusch and Pagan Lagrangian, Multiplier Test for Random Effects (Chibar2 of 10.68 with p-value of 0.0005). A PLS path modelling (Wold, 1974, 1985) using Smart PLS 2.0 M3 software (Ringle, Wende, \& Will, 2005) was employed to ascertain the internal consistency reliability and discriminant validity of the constructs used in the study. In particular, PLS Algorithm (Geladi \& Kowalski, 1986) was calculated to obtain the average variance extracted and the composite reliability coefficients. Bagozzi and Yi (1988) as well as Hair et al. (2011) suggested that the composite reliability coefficient should be at least .70 or more while, Fornell and Larcker (1981) suggested that the Average Variance Extracted (AVE) score should be .5 or more. They further stated that to achieve adequate discriminant validity, the square root of the AVE should be greater than the correlations among latent constructs. The PLS path modelling is considered as the most suitable technique in this work because PLS path modelling is similar to conventional regression. Further, this paper is explorative in nature giving that covid19 is novel and by applying change oriented leadership as a moderator requires a path modelling approach to be employed because it has been suggested that if research is prediction-oriented or an extension of an existing theory, PLS path modelling should be employed (Hair et al., 2011; Henseler, Ringle, \& Sinkovics, 2009; Hulland, 1999).

Also, compared to other path modelling software (e.g., AMOS; Analysis of Moment Structures), the Smart PLS 2.0 M3 software tool of analysis is a friendly graphical user interface, which help users create a moderating effect for path models with interaction effects (Temme, Kreis, \& Hildebrandt, 2006, 2010). The technique has the advantage of estimating the relationships between constructs (structural model) and relationships between indicators and their corresponding latent constructs (measurement model) simultaneously (Chin, Marcolin, \&Newsted, 2003; Duarte \& Raposo, 2010; Gerlach, Kowalski, \& Wold, 1979; Lohmöller, 1989).

\subsection{Measurement Variables}

The variables of the study are Psychological wellbeing, Academic, Approaches in education and finance models (dependent variables). 
Table 1: Variables Measurements

\begin{tabular}{|c|c|c|c|}
\hline $\begin{array}{l}\text { IV/ } \\
\text { moderator }\end{array}$ & Measurements & Variables : DV & Measurements \\
\hline $\begin{array}{l}\text { Covid19- } \\
\text { Lockdown }\end{array}$ & $\begin{array}{l}\text { Travel restriction, } \\
\text { mandatory school } \\
\text { closure, and restriction } \\
\text { of nonessential } \\
\text { commercial activities, } \\
\text { stay at home, social } \\
\text { distancing, hygiene } \\
\text { and washing of hands. }\end{array}$ & $\begin{array}{l}\text { Psychological } \\
\text { wellbeing }\end{array}$ & $\begin{array}{l}\text { Daily routine, access to } \\
\text { resource, adjustment to home } \\
\text { life, appetite and sleep, mood, } \\
\text { boredom, social Isolation }\end{array}$ \\
\hline \multirow[t]{3}{*}{$\begin{array}{l}\text { Change } \\
\text { oriented } \\
\text { leadership }\end{array}$} & $\begin{array}{l}\text { New and creative } \\
\text { ideas, confidence/ } \\
\text { optimism, long term } \\
\text { perspective, clear } \\
\text { appealing vision, } \\
\text { negotiation/ } \\
\text { persuasion, study of } \\
\text { competitor's product } \\
\text { change and activities }\end{array}$ & $\begin{array}{l}\text { Academic } \\
\text { disruptions }\end{array}$ & $\begin{array}{l}\text { Academic calendar, } \\
\text { examinations, Assessments, } \\
\text { teaching/ learning, learning } \\
\text { capacity, students' learning, } \\
\text { Research, in-person learning } \\
\text { practical, library usage }\end{array}$ \\
\hline & & $\begin{array}{l}\text { Shift in } \\
\text { education } \\
\text { Approaches }\end{array}$ & $\begin{array}{l}\text { Shift online, student-parent } \\
\text { home study, registration for } \\
\text { online courses, review of } \\
\text { curriculum, contact hours }\end{array}$ \\
\hline & & Finance Model & $\begin{array}{l}\text { Diversification of source of } \\
\text { income, cost reduction drive, } \\
\text { review of payments/salary, } \\
\text { renegotiation of finance } \\
\text { obligations, palliatives/ } \\
\text { financial support }\end{array}$ \\
\hline
\end{tabular}

\subsection{Results and Discussions}

The description of the data collected for the study and the moderating effect of change oriented leadership on the constructs are presented and discussed, the summary of results of the data are presented in Tables 2-8 as follows: Appendix 1 presents the report of interview. In addition to the moderating variable contribution, the interview helped to hear from source and direct from participants. Extracts from interview include: "government should seize the opportunity of the pandemic and its lessons to rejig its approach to governance and management of economy and social welfare interventions", "our leaders should innovate, rethink, look inward and re strategies", "leaders to should help in measures that would help SMEs transit and key into digital economy", "we as school owners, to mitigate the impact are looking at private equity and financing on how to support each other "Government should look into financial and non-financial palliative for SMEs", "leaders should help in measures that would help SMEs transit and key into digital economy, adaptation to technology is key in confronting the new order", "the surviving grace was that we creatively moved online, however, facility limitation still remains a challenge. Experience now has further shown that it is not possible to deploy e-learning in all the four cognitive areas of learning".

The reality of the lockdown is that virtual learning can only be complementary and not a substitute; lecturer-student contact is inevitable for complete and wholesome learning. We as a group resulted to advocacies to champion our course. The import from the interview was that as owners and leaders they try to promote exploration of new and better ways of doing things, or trying to uncover hidden potentials to reduce impact of covid19 which is line with and support change leadership proposition.

Table 2 describes the demographic profile of the participants in the survey. The demographic characteristics examined include gender, age group, marital status and category (student, staff, parents, business owner, and business operators). The demographic profile show that the majority of the participants in the survey were male, 151 representing $51.9 \%$, while 140 representing $48.1 \%$ were female. $28.2 \%$ of the participants were in the age group of 16- 25 years.

This is followed by age group under 16 years with 67 participants accounting for $23 \%$ of the participants. Table 2 further show that students were the highest participants with $169(58.1 \%)$ followed by staff 56 participants (19.2\%) and parents 49 participants $(16.8 \%)$. In addition, the table show that school owners and business operators on campus were the least participants with $7(2.4 \%)$ and $10(3.4 \%)$ respectively. Table 3 presents the results of measurement model, the average variance extracted and composite reliability coefficients of the latent constructs. Diagonals (bold face) represent the square root of the average variance extracted while the other entries represent the correlations. The essence of internal consistency reliability is to determine the extent to which all items on a particular scale are measuring the same concept (Bijttebier et al., 2000; Sun et al., 2007). In Table 4, the correlations among the latent constructs were compared with the square root of the average variances extracted (values in bold face). 
Table 6 shows that the square root of the average variances extracted were all greater than the correlations among latent constructs, suggesting adequate discriminant validity (Fornell \& Larcker, 1981). Cronbach's alpha coefficient and composite reliability coefficient are the most commonly used estimators of the internal consistency reliability of an instrument in organizational research (e.g., Bacon, Sauer, \& Young, 1995; McCrae, Kurtz, Yamagata, \& Terracciano, 2011; Peterson \& Kim, 2013). This study, in addition to Cronbach's alpha coefficient, composite reliability coefficient was also adapted to ascertain the internal consistency reliability of measures. Composite reliability coefficient provides a much less biased estimate of reliability than Cronbach's alpha coefficient because the later assumes all items contribute equally to its construct without considering the actual contribution of individual loadings (Barclay, Higgins, \& Thompson, 1995; Gotz, Liehr-Gobbers, \& Krafft, 2010).

Cronbach's alpha may over or under-estimate the scale reliability. The composite reliability takes into account that indicators have different loadings and can be interpreted in the same way as Cronbach's alpha (that is, no matter which particular reliability coefficient is used, an internal consistency reliability value above .70 is regarded as satisfactory for an adequate model, whereas a value below .60 indicates a lack of reliability). Nevertheless, the interpretation of internal consistency reliability using composite reliability coefficient was based on the rule of thumb provided by Bagozzi and Yi (1988) as well as Hair et al (2011), who suggest that the composite reliability coefficient should be at least .70 or more.

Discriminant validity refers to the extent to which a particular latent construct is different from other latent constructs (Duarte \& Raposo, 2010). In the present study, discriminant validity was ascertained using AVE, as suggested by Fornell and Larcker (1981). This was achieved by comparing the correlations among the latent constructs with square roots of average variance extracted (Fornell \& Larcker, 1981). Additionally, discriminant validity was determined following Chin's (1998) criterion by comparing the indicator loadings with other reflective indicators. First, as a rule of thumb for evaluating discriminant validity, Fornell and Larcker (1981) suggest the use of AVE with a score of .50 or more. Adequate discriminant validity, Fornell and Larcker (1981) further suggest that the square root of the AVE should be greater than the correlations among latent constructs.

As indicated in Table 5, the values of the average variances extracted range between 0.57 and 0.82 , suggesting acceptable values. In Table 4, the correlations among the latent constructs were compared with the square root of the average variances extracted (values in bold face). Table 4 also show that the square root of the average variances extracted were all greater than the correlations among latent constructs, suggesting adequate discriminant validity (Fornell \& Larcker, 1981). Table 5 also present discriminant validity result using Heterotraitmonotrait (HTMT) Furthermore, Table 3 help in establishing convergent validity, indicating the intended latent construct correlate with other measures of the same latent construct (Hair et al., 2006). The Average Variance Extracted (AVE) of each latent construct were in agreement with Fornell and Larcker (1981). Chin (1998) also recommends that the AVE of each latent construct should be .50 or more. Following Chin (1998), the AVE values (Table 3) exhibited high loadings (>.50) on their respective constructs, indicating adequate convergent validity.

\begin{tabular}{|l|c|c|}
\hline \begin{tabular}{l} 
Demographic Profile of Partipants $(N=291)$ \\
\hline
\end{tabular} & Frequency & Percentage \\
\hline Age Group & & \\
\hline Under 16 years & 67 & 23.0 \\
\hline 16 - 25 years & 82 & 28.2 \\
\hline 26 - 35 years & 40 & 13.7 \\
\hline 36 - 45 years & 41 & 14.1 \\
\hline 46 - 55 years & 46 & 15.8 \\
\hline 56 - 60 years & 15 & 5.2 \\
\hline Gender & & \\
\hline Male & 151 & 51.9 \\
\hline Female & 140 & 48.1 \\
\hline Marital Status & & \\
\hline Single & 169 & 58.1 \\
\hline Married & 122 & 41.9 \\
\hline Category & & \\
\hline Student & 169 & 58.1 \\
\hline Staff & 56 & 19.2 \\
\hline Parent & 49 & 16.8 \\
\hline School Owner & 7 & 2.4 \\
\hline Business operator on campus & 10 & 3.4 \\
\hline
\end{tabular}

Table 2 - Source: Field Result (2020) 


\begin{tabular}{|c|c|c|c|c|}
\hline \multicolumn{5}{|l|}{ Results of Measurement Model } \\
\hline Constructs and indicators & Loadings & $\begin{array}{c}\text { Cronbach's } \\
\text { Alpha }\end{array}$ & $\begin{array}{l}\text { Composite } \\
\text { Reliability }\end{array}$ & $\begin{array}{c}\text { Average } \\
\text { Variance } \\
\text { Extracted }\end{array}$ \\
\hline Covid 19 Lockdown & & 0.84 & 0.89 & 0.68 \\
\hline CVD02 & 0.77 & & & \\
\hline CVD03 & 0.82 & & & \\
\hline CVD04 & 0.86 & & & \\
\hline CVD05 & 0.85 & & & \\
\hline Change oriented leadership & & 0.88 & 0.91 & 0.63 \\
\hline COL01 & 0.84 & & & \\
\hline $\mathrm{COLO2}$ & 0.84 & & & \\
\hline COL03 & 0.82 & & & \\
\hline COL04 & 0.79 & & & \\
\hline COL05 & 0.65 & & & \\
\hline COL06 & 0.80 & & & \\
\hline Psychological well being & & 0.87 & 0.90 & 0.55 \\
\hline PSYW01 & 0.73 & & & \\
\hline PSYW02 & 0.73 & & & \\
\hline PSYW03 & 0.78 & & & \\
\hline PSYW04 & 0.76 & & & \\
\hline PSYW05 & 0.76 & & & \\
\hline PSYW06 & 0.75 & & & \\
\hline PSYW07 & 0.71 & & & \\
\hline Academic disruptions & & 0.95 & 0.96 & 0.71 \\
\hline ACD01 & 0.78 & & & \\
\hline $\mathrm{ACD} 02$ & 0.84 & & & \\
\hline $\mathrm{ACD} 03$ & 0.84 & & & \\
\hline ACD04 & 0.84 & & & \\
\hline ACD05 & 0.87 & & & \\
\hline ACD06 & 0.83 & & & \\
\hline $\mathrm{ACD} 07$ & 0.87 & & & \\
\hline ACD08 & 0.85 & & & \\
\hline ACD09 & 0.83 & & & \\
\hline Shift in educational approaches & & 0.89 & 0.92 & 0.70 \\
\hline SEA01 & 0.78 & & & \\
\hline SEA02 & 0.83 & & & \\
\hline SEA03 & 0.88 & & & \\
\hline SEA04 & 0.85 & & & \\
\hline SEA05 & 0.83 & & & \\
\hline Financial model & & 0.85 & 0.89 & 0.62 \\
\hline FNM02 & 0.75 & & & \\
\hline FNM03 & 0.71 & & & \\
\hline FNM04 & 0.78 & & & \\
\hline FNM05 & 0.88 & & & \\
\hline FNM06 & 0.81 & & & \\
\hline
\end{tabular}

Table 3 - Source: Field Result (2020) 


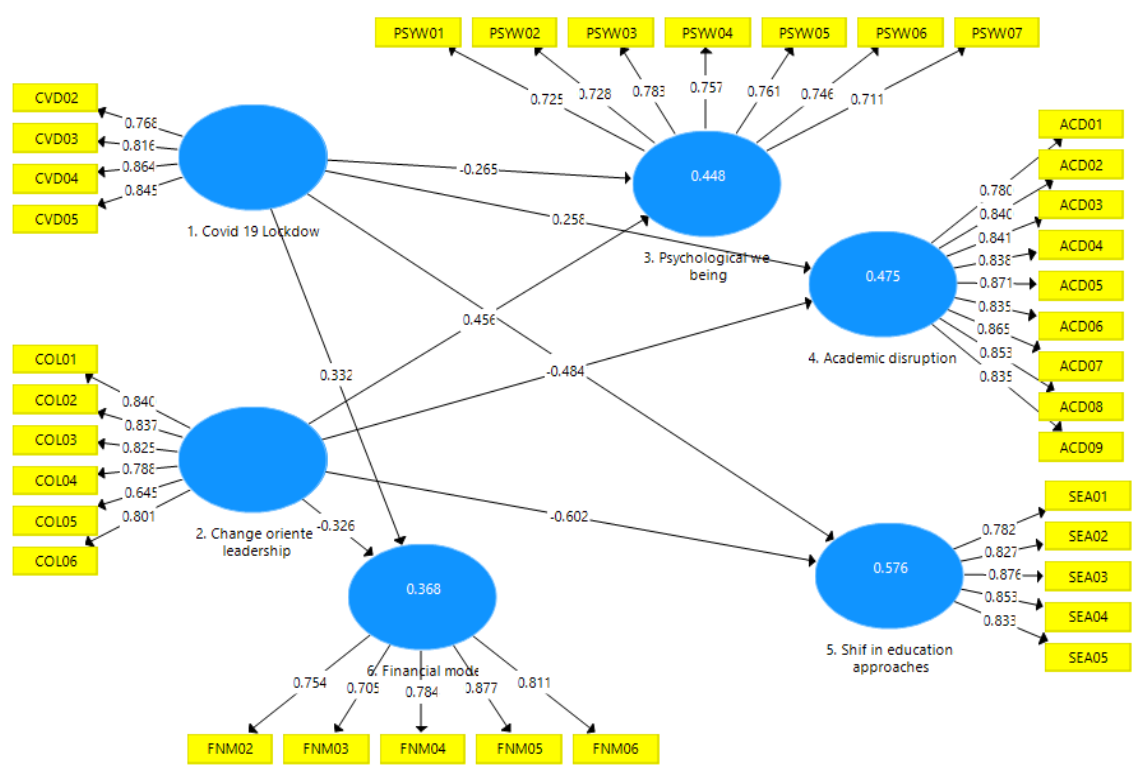

Figure 2 - Source: Field Result (2020)

As indicated in Table 4, the composite reliability coefficient of each latent construct ranged from 0.79 to 0.82 each exceeding the minimum acceptable level of .70 , which also suggests adequate internal consistency reliability of the measures used (Bagozzi \& Yi, 1988; Hair et al., 2011). Likewise, as indicated in Table 3, the values of the average variances extracted range between .55 and .71 , suggesting acceptable values. Regarding the discriminant validity, Table 6 compares the correlations among the latent constructs with the square root of AVE.

\begin{tabular}{|l|c|c|c|c|c|c|}
\hline Results of Discriminant Validity using Fornell-Larcker Criterion & & & \\
\hline Constructs & $\mathbf{1}$ & $\mathbf{2}$ & $\mathbf{3}$ & $\mathbf{4}$ & $\mathbf{5}$ & $\mathbf{6}$ \\
\hline 1. Covid 19 Lockdown & $\mathbf{0 . 8 2}$ & & & & & \\
\hline 2. Change oriented leadership & -0.70 & $\mathbf{0 . 7 9}$ & & & & \\
\hline 3. Psychological well being & -0.58 & 0.64 & $\mathbf{0 . 7 4}$ & & & \\
\hline 4. Academic disruptions & 0.60 & -0.66 & -0.71 & $\mathbf{0 . 8 4}$ & & \\
\hline 5. Shift in educational approaches & 0.63 & -0.75 & -0.58 & 0.63 & $\mathbf{0 . 8 3}$ & \\
\hline 6. Financial model & 0.56 & -0.56 & -0.49 & 0.44 & 0.52 & $\mathbf{0 . 7 9}$ \\
\hline
\end{tabular}

Table 4 - Source: Field Result (2020)

To assess significance of the path coefficients (Hair et al., 2014; Hair et al., 2011; Hair et al., 2012; Henseler et al., 2009). Figure 2 and Table 7 therefore show the estimates for the full structural model, which includes moderator variable (Change oriented leadership).

Fig 1

Results of Discriminant Validity using Heterotrait-Monotrait Ratio (HTMT) Criterion

\begin{tabular}{|l|c|c|c|c|c|c|}
\hline Constructs & $\mathbf{1}$ & $\mathbf{2}$ & $\mathbf{3}$ & $\mathbf{4}$ & $\mathbf{5}$ & $\mathbf{6}$ \\
\hline 1. Covid 19 Lockdown & & & & & & \\
\hline 2. Change oriented leadership & 0.82 & & & & & \\
\hline 3. Psychological well being & 0.68 & 0.73 & & & & \\
\hline 4. Academic disruptions & 0.67 & 0.73 & 0.78 & & & \\
\hline 5. Shift in educational approaches & 0.72 & 0.83 & 0.66 & 0.69 & & \\
\hline 6. Financial model & 0.65 & 0.63 & 0.56 & 0.47 & 0.57 & \\
\hline
\end{tabular}

Table 5 - Source: Field Result (2020) 
Results of Cofficients of Determination ( $R$ Square values)

\begin{tabular}{|l|c|c|}
\hline Endogenous Constructs & $\boldsymbol{R}^{\mathbf{2}}$ & $\boldsymbol{Q}^{\mathbf{2}}$ \\
\hline Psychological well being & 0.45 & 0.23 \\
\hline Academic disruptions & 0.48 & 0.31 \\
\hline Shift in educational approaches & 0.58 & 0.37 \\
\hline Financial model & 0.37 & 0.21 \\
\hline
\end{tabular}

Table 6 - Source: Field Result (2020)

Results of Effect Sizes (f Square values)

\begin{tabular}{|l|c|c|c|c|}
\hline Exogenous Constructs & $\begin{array}{c}\text { Psychological } \\
\text { well being }\end{array}$ & $\begin{array}{c}\text { Academic } \\
\text { disruptions }\end{array}$ & $\begin{array}{c}\text { Shift in } \\
\text { educational } \\
\text { approaches }\end{array}$ & $\begin{array}{c}\text { Financial } \\
\text { model }\end{array}$ \\
\hline Covid 19 Lockdown & 0.06 & 0.06 & 0.05 & 0.09 \\
\hline Change oriented leadership & 0.19 & 0.23 & 0.43 & 0.09 \\
\hline
\end{tabular}

Table 7 - Source: Field Result (2020)

As shown in Table 8 below, all hypotheses except H9 and H12 were supported. Table 8 and Fig 3 show the full structural model including the moderating effect. As earlier discussed, the reliability of measure was okay since the values were greater than 0.6 . Table 6 suggest that the predictive reliance $\left(\mathrm{Q}^{2}\right)$ variables were greater than zero and exceed the threshold. Further the $\mathrm{R}^{2}$ were in line with literature of 0.1 and above hence the hypotheses supported. According to Henseleret et al. (2009), a research model with $Q^{2}$ statistic (s) greater than zero is considered to have predictive relevance. Additionally, a research model with higher positive $Q^{2}$ values suggests more predictive relevance. Table 8 and fig 3 also shed light on moderation effects. This was the core of this study. Unlike other researches on similar studies on previous epidemics that emphasize on the impact of the deceases, this study introduced a moderating variable (Change oriented leadership). Covid19 is a pandemic that caught the world by shock. Therefore, to the best of our knowledge not much has been established, hence this study qualifies as exploratory study. The main hypotheses, in particular show significant relation between change-oriented leadership and academic disruption, psychological well-being, finance model and shift in education approaches. For example, academic disruption is not desirable, while psychological well-being is something desirable. Results in this study show that the relationship between change oriented leadership and academic disruption was negative but positive in the sense that as lockdown is affecting academics, high oriented leaders were bringing solutions such as reading material via Google Classroom, were augmented with synchronous face-to-face video instruction, to help pre-empt school closures and to reduce the impact. Similarly, the interaction and relationship with financial model was significant but also positive. This could be justified as a result of increase in expenditure profile such purchase of more computer, data purchase and other associate cost doe to new ways of operation. Importantly, concerning the moderating effects of change oriented leadership on the relationship between the four predictor variables, PLS path coefficients revealed that of the 12 formulated hypotheses, 10 were supported.

\begin{tabular}{|c|c|c|c|c|c|c|}
\hline \multicolumn{7}{|c|}{ Results of Structural Model } \\
\hline Hypotheses & Relationships & Beta & SE & t-value & p-value & Findings \\
\hline H1 & Covid 19 Lockdown -> Psychological well being & -0.26 & 0.07 & 4.01 & 0.00 & Supported \\
\hline $\mathrm{H} 2$ & Covid 19 Lockdown -> Academic disruptions & 0.24 & 0.05 & 4.46 & 0.00 & Supported \\
\hline $\mathrm{H} 3$ & Covid 19 Lockdown -> shift in educational approaches & 0.21 & 0.06 & 3.62 & 0.00 & Supported \\
\hline $\mathrm{H} 4$ & Covid 19 Lockdown -> Financial model & 0.34 & 0.06 & 5.54 & 0.00 & Supported \\
\hline H5 & Change oriented leadership -> Psychological well being & 0.46 & 0.07 & 6.89 & 0.00 & Supported \\
\hline H6 & Change oriented leadership -> Academic disruptions & -0.57 & 0.05 & 11.85 & 0.00 & Supported \\
\hline H7 & Change oriented leadership -> shift in educational approaches & -0.59 & 0.05 & 10.76 & 0.00 & Supported \\
\hline $\mathrm{H} 8$ & Change oriented leadership -> Financial model & -0.27 & 0.06 & 4.36 & 0.00 & Supported \\
\hline H9 & Covid 19 Lockdown x Psychological well being -> Psychological well being & 0.01 & 0.04 & 0.16 & 0.44 & Not supported \\
\hline H10 & Covid 19 Lockdown x Academic disruptions-> Academic disruptions & -0.29 & 0.02 & 12.08 & 0.00 & Supported \\
\hline H11 & Covid 19 Lockdown $\mathrm{x}$ shift in educational approaches $->$ Financial model & 0.16 & 0.03 & 5.07 & 0.00 & Supported \\
\hline $\mathrm{H} 12$ & Covid 19 Lockdown x Financial model -> shift in educational approaches & 0.03 & 0.03 & 0.85 & 0.20 & Not supported \\
\hline
\end{tabular}

Table 8 - Source: Field Result (2020) 
Flowing from the qualitative and quantitative data analysed and discussed and as previously mentioned, this study focused on theory testing and verification rather than developing a new theory, thus, employing a deductive research approach. The model theorised that a high change oriented leadership will introduce strategies to reduce impact of lockdown while low oriented leadership will not. This has been evidently proven. The lesson learnt is that leadership in schools, organizations and governments should adopt the change oriented leadership style to build resilience to face various threats and perhaps develop skills for informed decision making, creative problem solving, and more importantly adaptability.

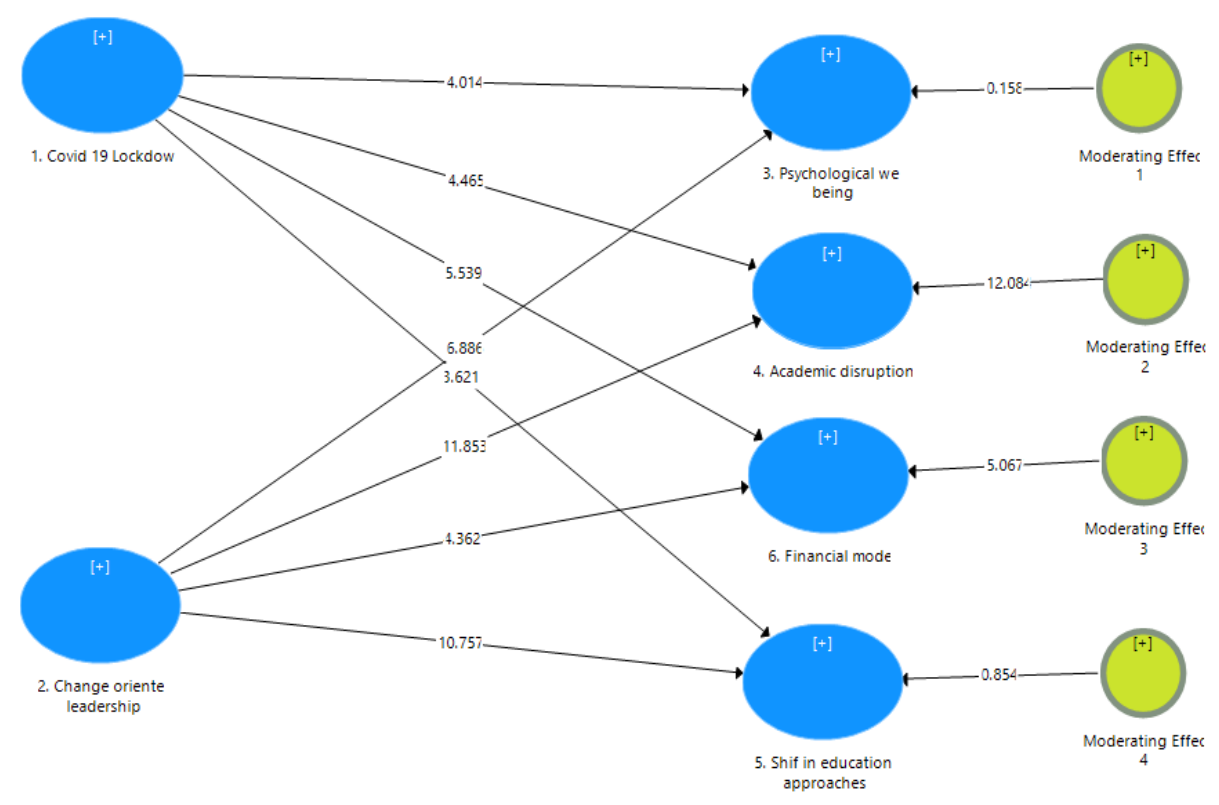

Fig 3 - Source: Field Result (2020)

\subsection{Conclusions}

Based on empirical and theoretical gaps, it was conceptualised that change oriented leadership role as a moderating value can explain the relationship and perspectives with the dependent variables. This paper adopts regression research design in the analysis specifically, smart PLS modelling was used. The study has implications on students, parents, leadership of schools, operators of businesses on campus. The study further provides concept deployment, evidence from Federal Capital Territory (FCT), Nigeria and useful addition to theory, literature and practice. The study found that 10 of the 12 hypotheses were supported and 2 unsupported in particular, the study found that the results from this study lend support to the theoretical proposition in change oriented leadership. While there have been many studies examining the impact of Covid19 on different fields, however, this present study addressed the theoretical gap by incorporating change oriented leadership as a significant moderating variable. This study further lends theoretical and empirical support for the moderating role of change oriented leadership between Covid 19 Lockdown and psychological well-being, academic disruption, shift in education approaches and Financial Model. The conceptual framework of this study has also added to the domain of leadership theory by examining the impact of change oriented leaders in turbulent environment. Also the findings from this study provide some important practical implications to private school owners as well as business operators' and the society at large. Furthermore, the blend of interviews using the 6 items unidimensional construct (Yuki, 1999) provided direct information from source and participants making the work uniquely different. Even though the timing of this study is a short period of schooling lockdown, the effect provides a guide to reasonably peep into likely possible outcomes as an extremely rough measure of the impact of the current school closures. The real quantitative impact will be better analysed post lockdown and covid19 era. Admittedly, sample used and the concentration on Federal Capital Territory (FCT) may no bet strong enough to generalise These limitations of the current study, could pave way for several future research directions. In conclusion, the present study has added valuable theoretical, practically and methodologically to the growing body of knowledge in the field of social sciences and management and support practical decision making. 


\section{References}

Adair, J. (1983). Effective Leadership. London, Pan.

Andersen, S C, and H S Nielsen (2019), "Learning from Performance Information", Journal of Public Administration Research and Theory.

Arvonen, J. (2008). Change-oriented leadership behaviour: A consequence of post-bureauratic organisations? The Routledge Companion to Creativity (1 ed., pp. 302-313). London: Routledge

Bacon, D. R., Sauer, P. L., \& Young, M. (1995). Composite reliability in structural equations modeling. Educational and Psychological Measurement, 55, 394-406. doi: 10.1177/0013164495055003003

Bagozzi, R., \& Yi, Y. (1988). On the evaluation of structural equation models. Journal of the Academy of Marketing Science, 16, 74-94. doi: 10.1007/bf02723327

Bjorklund, A and K Salvanes (2011), "Education and Family Background: Mechanisms and Policies", in E Hanushek, S Machin and L Woessmann (eds), Handbook of the Economics of Education, Vol. 3.

Chin, W. W., Marcolin, B. L., \&Newsted, P. R. (2003). A partial least squares latent variable modeling approach for measuring interaction effects: Results from a Monte Carlo Simulation study and an electronic-mail emotion/adoption study. Information Systems Research, 14, 189-217. doi: 10.1287/isre.14.2.189.16018

(COVID-19) Outbreak in China: Summary of a Report of 72314 Cases from the Chinese Center for Disease Controland Prevention," JAMA, February 24, 2020.

COVID-19: Joint Actions to Win the War, Organization for Economic Cooperation and Development, March 23, 2020. https://www.oecd.org/coronavirus/\#op-ed.

Disease 2019 (COVID-19), February 16-24, 2020

(https://www.who.int/docs/default-source/coronaviruse/whochina-joint-mission-on-covid-19-finalreport.pdf).

Fornell, C., \& Larcker, D. F. (1981). Evaluating Structural Equation Models with unobservable variables and measurement error. Journal of Marketing Research 18, 39-50.

Forward, S. E. (2009). The theory of planned behaviour: The role of descriptive norms and past behaviour in the prediction of drivers' intentions to violate. Transportation Research Part

Gotz, O., Liehr-Gobbers, K., \&Krafft, M. (2010). Evaluation of Structural Equation Models using the Partial Least Squares (PLS) Approach. In V. E. Vinzi, W. W. Chin, J. Henseler\& H. Wang (Eds.), Handbook of Partial Least Squares: Concepts, Methods and Applications (pp. 691-711). Heidelberg: Springer.

Hair, J. F., Ringle, C. M., \&Sarstedt, M. (2013). Partial least squares structural equation modeling: Rigorous applications, better results and higher acceptance. Long Range Planning, 46(1-2), 1-12. doi: http://dx.doi.org/10.1016/j.lrp.2013.01.001

Kura, K. M., Shamsudin, F. M., \& Chauhan, A. (2013a). Influence of organizational formal control on workplace deviance: A pilot study. Middle-East Journal of Scientific Research, 13, 538-544 doi: 10.5829/idosi.mejsr.2013.13.4.312

Lee, A and Cho, J (2016) "The impact of epidemics on labor market: identifying victims of the Middle East Respiratory Syndrome in theKorean labor market" in International Journal Equity Health. 2016

Majid, G Sufean. H (2014) Theories of Educational Management and Leadership: A Review Conference Paper

Mapping the Spread of the Coronavirus in the U.S. and Worldwide, Washington Post Staff, The Washington Post, March 4, 2020. https://www.washingtonpost.com/world/2020/01/22/mapping-spread-newcoronavirus/?arc404=true.

McKibbin, W. and R. Fernando (2020) The Global Macroeconomic Impacts of COVID-19: Seven Scenarios.https://www.brookings.edu/research/the-global-macroeconomic-impacts-of-covid-19-sevenscenarios/

OECD Interim Economic Assessment: Coronavirus: The World Economy at Risk, Organization for Economic Cooperation and Development. March 2, 2020. http://www.oecd.org/economic-outlook/\#resources.

WHO-China Joint Mission on Coronavirus Disease 2019, Report of the WHO-China Joint Mission on Coronavirus

Ringle, C. M., Wende, S., \& Will, S. (2005). SmartPLS 2.0 beta: University of Hamburg, Hamburg. Retrieved from http://www.smartpls.de/forum/index.php.

Yuki (1999) "Change- oriented leadership as aunidimensional construct with 6 items"

Z. Wu and J. M. McGoogan, "Characteristics of and Important Lessons from the Coronavirus Disease 2019www.ledelsesbarometer.dk (general information in Danish)

www.org.hha.dk/org/ddl (specific research information 


\section{APPENDIX}

Extracts from interview include:

"Government should seize the opportunity of the pandemic and its lessons to rejig its approach to governance and management of economy and social welfare interventions"

" Our leaders should innovate, rethink, look inward and re strategies"

"leaders to should help in measures that would help SMEs transit and key into digital economy,"

"We as school owners, to mitigate the impact are looking at private equity and financing on how to support each other"

"Government should look into financial and non-financial palliative for SMEs"

"The surviving grace was that we creatively moved online"

"We as a group resulted to advocacies to champion our course". 